\title{
Extent of Institutional Autonomy in Determination of Content and Quality of University Education in Uganda
}

\author{
Denis Thaddeus Ofoyuru ${ }^{1}$, Rashid Lukwago ${ }^{1} \&$ Joseph Kimoga $^{1}$ \\ ${ }^{1}$ College of Education and External Studies, Makerere University, Uganda \\ Correspondence: Denis Thaddeus Ofoyuru, College of Education and External Studies, Makerere University, \\ Uganda.
}

Received: March 30, 2016

Accepted: April 22, 2016

Online Published: June 17, 2016

doi:10.5430/irhe.v1n2p64

URL: http://dx.doi.org/10.5430/irhe.v1n2p64

\begin{abstract}
Outcry about deplorable content and quality of university education in Uganda is widespread. Yet, studies about the same are rare. This paper explored the extent of institutional autonomy in the determination of content and quality of university education in Uganda. The political model of university governance was the guiding theory. Findings revealed that the government, the National Council for Higher Education, and universities determine the content and quality of university education. We conclude that partial institutional autonomy is inherent in the determination of content and quality of university education in Uganda. However, we recommend that universities should be accorded more institutional autonomy in order to achieve better content and quality of education suitable for national development.
\end{abstract}

Keywords: institutional autonomy, content, quality, academic freedom

\section{Introduction}

Outcry about deplorable content and quality of university education in Africa is widespread (Teferra, 2014; Bloom, Cunning, Chan and Luca, 2014). The situation in Uganda is not any better (National Council for Higher Education [NCHE], 2013). A number of factors such as academic staff quality, inadequate infrastructure and poor funding have been blamed for poor quality of university education (Kasozi, 2009, NCHE, 2011, Teferra, 2014; Bloom, Cunning, Chan \& Luca, 2014). Asiimwe and Steyn (2013) point out that government interference with university autonomy undermines university governance. Yet, Appyagyei-Atua, Beiter and Karran (2015) maintain that university autonomy in Africa has been drastically downtrodden over the years for a number of reasons, mainly political and ideological. However, studies about institutional autonomy and content and quality of university education in Uganda are hard to come by.

This paper was therefore occasioned by the need to explore the extent of institutional autonomy in the determination of content and quality of university education in Uganda. Using the interpretive approach anchored on the constructivist ontology that reality is subjective and not a given and the epistemological assumption that knowledge is subjective and tentative and not static and therefore multiple and paradoxical interpretation is tenable. We used document review as a method of data collection and thematic constant comparative analysis for data analysis. The study was guided by the political model of university governance as the guiding theory.

Findings revealed that the government, the National Council for Higher Education, and universities determine the content and quality of university education. We conclude that partial institutional autonomy is inherent in the determination of content and quality of university education in Uganda. We therefore recommend that universities should be accorded more institutional autonomy in order to achieve better content and quality of education suitable for national development.

\section{Definition of Concepts}

According to Chiang (2004) university autonomy means the university's power to manage or govern itself without undue interference. It is therefore implicit that, while autonomy must be enjoyed, responsibility should be exercised in doing so. To that extent if such responsibility is seen to be lacking, the powers and body that regulate higher education in a given country should be duty bound, to regulate the affairs of a university. The concept institutional 
autonomy and academic freedom are interlocked and intertwined and therefore may not effectively be treated in isolation.

According to Taiwo (2011) academic freedom in a broad sense includes institutional autonomy, but the two terms are conceptually different. While institutional autonomy relates to the corporate independence of an institution from the state, academic freedom subsumes both the corporate autonomy of the university and the freedom of faculty and student in learning and in research. Taiwo therefore argues that academic freedom and university autonomy are inseparable. Dee, Henkin and Chen (2000) and Kasozi (2009) alludes that institutional autonomy and faculty autonomy are not synonymous but the former underpins the latter.

Quality is a measure of excellence; observable and interpretable features or the adherence to measurable and verifiable standards (Business Dictionary, 2015). According to Shatri and Alli (2010), quality in education means consistency, fitness for purpose, value for money and transformation. Consistency involves specifications through zero defect approach and a quality culture. Fitness for purpose means fitting the customer specifications purpose and customer satisfaction. Value for money means best outcome achieved through efficiency and effectiveness. Education is transformative if it achieves empowerment and enhancement of the students. We operationally define quality of education as acquisition by students, of generic, professional and technical skills and knowledge which meet the work place requirements and equip students with generic competencies.

\section{Literature Review}

Ngome (2003) pointed out that in Kenyan public universities; power is concentrated in the hands of the Vice-Chancellors. However, being presidential appointees, the Vice-chancellors tread a very tight rope, of trying to be in control and ensure allegiance to one's regime. The appointment of Vice-Chancellors and Principals of constituent colleges by the Presidency outlines a scenario of external imposition, which puts institutional autonomy at stake thereby undermining quality of teaching and research.

Fisher (1988) examined the relationship between state legislation and institutional autonomy in Europe and found that all the Acts passed did not have any clauses seeking to curtail university autonomy. However, there was indication from the higher education institutions studied that the state or its agents occasionally intruded in the affairs of the higher education institutions thus undermining their institutional autonomy. A feeling that institutions were at the verge of losing their institutional autonomy was widespread. Fisher's study provides an interesting piece on institutional autonomy albeit, not from the point of view of content and quality of university education, leaving a question that deserves to be pursued in a scholarly mode.

Universities UK (2015), points that a number of external regulatory mechanisms exist in university education in the UK to assure quality of content, teaching and research. This is apparent that institutional autonomy is partially exercised in the determination of content and quality of university education in the UK. However the partial institutional autonomy has promoted quality, making university education in the UK a success story. The external regulatory agencies have helped improve quality rather than undermine it.

A study by Okai and Worlu (2014) in Nigeria suggests that academic staffs are quite aware of the concept of university autonomy. The study further revealed that the lecturers are free to carry out their teaching, pass and fail students without any external encumbrance. The study concluded though that, whereas the knowledge about institutional autonomy is pervasive, in practice institutional autonomy remained low. This situation is similar to a study by Varghese and Martin (2014) in China and Vietnam, which suggest that there is considerable degree of university autonomy in respect to determination of content and quality of education. Varghese and Martin (2014) however maintain in their study of five Asian Countries that the translation of autonomy from an abstract concept to an operational practice depends on the strength of the institutional leadership. The stronger the leadership the higher the autonomy and the reverse is true.

Visalsok, Ngoy and Virak (2014) study suggests that institutional autonomy is highly practiced in Cambodia in respect to determination of quality of university education. The authors however, note that unintended consequences of operationalising university institutional autonomy showed. This was seen in the subsequent high enrollment which led to increased faculty workload and resultant decline in quality. Whereas institutional autonomy was granted and operationalised, regulatory measures by government were in place to ensure quality in higher education. This partly agrees with Yamamoto and Futao (2014) who observed that institutional autonomy in Japanese higher education was regulated by government agencies.

According to Li and Yang (2014) university autonomy in China is apparent, with laws enacted to provide university autonomy including the freedom to determine the content of their education and how to deliver it. However, 
government retains the power to regulate the provision of higher education in the country. These findings are in tandem with Visalsok, Ngoy and Virak (2014) in a similar study in Cambodia.

Nizam and Nurdin (2014), using the case of Gadjah Mada University (UGM) point out that there is considerable extent to which institutional autonomy is applied in determining the content and quality of university education in Indonesia. The authors cite academic assessment, academic audit and programme development internal quality processes within the university which happen without any interference from government. They explicate that, Faculty Deans are free to propose academic programmes and have them vetted and passed by the Senate; and approved by the Board of Trustees without having to reach the Directorate General for Higher Education.

According to Thinh and Phuong (2014) freedom to determine content and quality of university education in Vietnam is partial. It includes the freedom to launch new academic programmes, teach, assess and award degrees. Decisions to establish or merge academic departments are also left to the institution without any external encumbrance. Whereas universities are free to develop and launch academic programmes, such programmes can only be launched when they are approved by the Ministry for Education and Training (Thinh \& Phuong, 2014). This is contrary to what happens in Indonesia according to Nizam and Nurdin (2014) where academic programmes at autonomous universities are mounted without central government agencies having to vet and approve.

Akalu (2014) points out that, although by law public universities in Ethiopia are to enjoy autonomy, such autonomy is in practice highly suppressed. The heavy raid on institutional autonomy appears to be occasioned by unprecedented increase in undergraduate enrolment (over 1200\%) in the recent years. Overwhelmed by the massive enrolment and put under pressure to uphold quality, the Ministry of Education interferes with institutional autonomy in all its domains: governance, human resource, faculty training, student admission and the very core of determining what to teach. This is typical of the teacher training curriculum which was developed by the Ministry of Education for all public universities. A more extreme suppression of institutional autonomy is evident in Zimbabwe. According to Global Coalition to Protect Education from Attack (2013) the Zimbabwean government is in stark violation of institutional autonomy in higher education. This is done through a string of spies located in all classrooms and all over the campuses to spy over academics suspected or known to be anti-government. Threats, arrests, imprisonment and denial of privileges for academics for teaching anti-government contents have also been experienced.

In Uganda, there is no explicit legal provision entrenching institutional autonomy per se, but academic freedom has been lumped up and tackled together with other freedoms under the bill of rights. Thus, chapter 4, section 29 (b) of the 1995 constitution grants every citizen "freedom of thought, conscience and belief which shall include academic freedom in institutions of learning". However, the Universities and Other Tertiary Institutions Act Section 23 (1) stipulates that "the university shall be a body corporate with perpetual succession and a common seal and may sue or be sued in its corporate name and subject to this Act, may do all other things as body corporates lawfully do" (UOTIA, 2001). Whereas this provision is implicit of institutional autonomy, there are a lot of caveats thereof. For instance according to the same Act, it is the national council which sets admission standards, may grant or deny accreditation of academic programmes and so on.

Bunoti (2010) in a study carried out in Uganda avers a plethora of institutional factors responsible for the content and quality of education in universities in Uganda. She cites low commitment by lecturers, theoretical teaching approaches and proliferation of university academic programmes as factors watering down quality. It is therefore implicit that the presence of institutional autonomy and not its absence is the major factor affecting content and quality of university education positively or negatively, in the case of Uganda.

\section{The Theory}

The political model of university governance cited in Baldrige (1971) was adopted as the interpretive framework for this study. The basic assumptions of the framework are as follows:

1. Conflict is natural and is to be expected in a dynamic organization. It is not abnormal, nor is it necessarily symptomatic of a break-down in the university community.

2. The university is fragmented into many power blocs and interest groups, and it is natural that they will try to influence policies and decisions.

3. In the university, as in other organizations, small groups of political elites govern most of the major decisions.

4. In spite of this control by elites, there is a democratic tendency in the university, just as there is in the larger society. 
5. Formal authority, as prescribed by the bureaucratic system, is limited by the political pressure and bargaining power that groups can exert against authorities.

6. External interest groups have a great deal of influence on the university. Internal groups do not have the power to make policies and decisions in a vacuum.

The political model of university governance is relevant to institutional autonomy because it avers decision making mode within the university as collegial, democratic and autonomous. However, the sixth assumption puts a caveat on institutional autonomy with a clear insinuation that complete autonomy is impossible; with external power blocs always inevitably influencing affairs within universities. In this paper, it is acknowledged that whereas scholars participate heavily in academic affairs of the university, the government through direct and indirect means is seen to weigh heavy influence on determination of content and quality of university education.

\section{Methods}

This study was interpretive involving a review of documents such as The Universities and Other Tertiary Institutions Act (2001 as amended 2003 and as amended 2006); the constitution of the Republic of Uganda (1995); Makerere university annual reports (2012, 2013 \& 2014), Muni University five year strategic plan (2011); Gulu University strategic plan (2009), Gulu University annual report, (2014), National Council for Higher Education: Checklist for Quality (2001), Quality assurance framework (2008), Quality assurance framework (2011), The state of higher education in Uganda (2010) and (2013) and Statutory instrument 2005, No. 85. The documents were analysed in a constant comparative manner. Relevant sections were synchronised and themes were developed providing a basis for discussion, conclusion and recommendations. The documents reviewed were representative since further review did not reveal additional information on determination of content of university education.

\section{Findings and Discussions}

A number of themes emerged from the review of the documents cited above and these were tabulated below as the summary of findings which in turn guided the discussions and conclusions. There were no contradictions on in the emerging themes. The discussions were particularly based on the sub-themes.

Table 1. Emerging themes on determination of content and quality of university education

\begin{tabular}{|c|c|c|}
\hline Code & Theme & Sub-Theme \\
\hline \multirow[t]{4}{*}{ GDR } & \multirow{4}{*}{$\begin{array}{l}\text { Government's Direct Role in Determination } \\
\text { of Content and Quality of University } \\
\text { Education }\end{array}$} & Enacting Laws Regarding University Education \\
\hline & & Establishing Organs Responsible for $\mathrm{HE}$ \\
\hline & & $\begin{array}{l}\text { Establishment of Public Universities with Specific } \\
\text { Mandates }\end{array}$ \\
\hline & & $\begin{array}{l}\text { Direct Advice and Instructions by the Minister } \\
\text { Responsible for Education }\end{array}$ \\
\hline \multirow[t]{5}{*}{ GIR } & \multirow{5}{*}{$\begin{array}{l}\text { Government's Indirect Role through National } \\
\text { Council for Higher Education }\end{array}$} & Issuing Letter of Interim Authority \\
\hline & & Issuance of License/Institutional Accreditation \\
\hline & & Grant of Charter \\
\hline & & Programme Accreditation \\
\hline & & Developing Quality Assurance Guidelines \\
\hline \multirow[t]{5}{*}{ UDR } & \multirow{5}{*}{$\begin{array}{l}\text { Universities Direct Role in Determining } \\
\text { Content and Quality of Education }\end{array}$} & Developing New Academic Programmes \\
\hline & & Review of Old Academic Programmes \\
\hline & & Implementing Teaching and Learning \\
\hline & & Implementing Guidelines for QA \\
\hline & & Approval of Academic Programmes by Senate \\
\hline
\end{tabular}

Source: Document Reviews (2015) 
Public universities are normally established by Act of Parliament with specific mandates. For instance, Mbarara University of Science and Technology was established to promote science and technology in Uganda as depicted in its name and mission "to be a centre of academic and professional excellence in science and technology" (Mbarara University of Science and Technology, 2015). Gulu University was established to promote agricultural and environmental courses (Gulu University, 2014). According to the President, however, these universities normally deviate from their raison d'être. As a result the government either through direct advice by the minister responsible for education or visitation committees, has occasionally cautioned universities about offering courses of study which are not relevant to national development. In addition, there has been a constant call by the government upon universities to offer programmes of studies which are critical to national aspirations. For instance, the president in 2013 asked Makerere University to scrap off irrelevant courses and re-echoed how he directed Mbarara University of Science and Technology to scrap off Bachelor of Development Studies, which they did (Anguyo, in press 2014). It is clearly evident that the government through its chief executive determines what goes on in universities. This is similar to what happens in Ethiopia according to Akalu (2014) and in Zimbabwe according to Global Coalition to Protect Education from Attack (2013); however the situation in Ethiopia and Zimbabwe seem to be more compelling.

Programme accreditation by universities has its legal basis in the laws that establish universities enacted by the Parliament. In the case of Uganda, the Universities and Other tertiary Institutions Act (2001) which charges the National Council for Higher Education with the function among others "to ensure minimum standards for courses of study and the equating of degrees, diplomas and certificates awarded by the different public and private institutions of Higher Education in Uganda" (UOTIA, 2001, 5[i]) is the legal basis for programme accreditation. By this clause, the NCHE is established as the body that at the system wide level has the mandate to determine the nature and quality of academic programmes in Universities. Autonomy is therefore a concept which is qualified as in Universities Act cap 210B which provides explicit autonomy while at the same time emphasizing responsibility, obligations and standards. Therefore autonomy is partial but the degree varies as suggested by other scholars such as Thinh and Phuong (2014) and Visalsok, Ngoy and Virak (2014) who indicated in separate studies that government agencies have to accredit academic programmes in Vietnam and Cambodia respectively before such programmes can be launched.

For private universities, the legality in determining content of their curricula starts remotely with issuing letter of interim authority, moves on to accreditation and then to the grant of a charter, all of which are enshrined in the law enacted by the parliament. In provision of letter of interim authority, the National Council for Higher Education lays the ground for a number of things. The letter of interim authority among other things states the vision, mission, objectives and the philosophy for which the university stands (Republic of Uganda, 2006; NCHE, 2008). It therefore follows that if the vision, mission, objectives and philosophy of the founders depict or imply that the promoters are likely to render education which is not in line with the guidelines of the Council then they are likely to be denied the letter of interim authority. For accreditation a number of detailed institutional parameters are prescribed by the council: classroom, library space, science laboratories, computer laboratories, administrative staff, and academic staff (NCHE, 2001; 2011) for the university to be accredited. If a chattered private university is not being run in a proper manner, particularly if its academic programmes are deemed to be substandard, the charter may be revoked (Republic of Uganda, 2001). This entails that autonomy is never absolute whether for public or private universities as argued by Dee, Henkin and Chen (2000) and Taiwo (2011).

In operationalising the law, NCHE (2008) quality assurance guidelines provide that,

All courses offered in institutions of higher learning must: adhere to minimum standards for courses of study set by the NCHE; enhance and operationalize the credit accumulation and transfer system for Uganda's higher education sub-sector developed by the NCHE; ensure that students learn basic elements of any course they study; guarantee value for money to students and parents; and enhance the quality of higher education delivered in institutions of higher learning. As much as institutional autonomy may be enjoyed, it should be enjoyed then within the confines of the law, as such the university shall be a body corporate and do anything that body corporate may lawfully do (Republic of Uganda, 2001). Therefore, operationalising the law and being held accountable to follow it may not be interpreted as an infringement on institutional autonomy, to that effect it may be asserted that the law is meant to guide institutional autonomy.

The practice in Uganda is that the academic staff in universities develops academic programmes based on their own prior qualification, experience or exposure. Such programmes are developed without interference from any agency whether from the industry or government, in this case enabling the individual academic staff to enjoy individual autonomy or academic freedom. Since, in most cases, individual autonomy reflects institutional autonomy, Ojo 
(1990) argues that university autonomy includes (a) the freedom of universities to select their students and staff through criteria chosen by the universities themselves; (b) freedom to develop their curriculum and syllabi among others. Review of academic programmes, just like development of curricula is done by experts in the disciplinary fields. In a mode akin to development of new programmes, experts in disciplinary fields review curricula based on their experience of teaching the course, feedback from students, developments or emerging themes in the field. Reviewed programmes go through steps such as departmental review, academic board and senate's approval before submission to the NCHE. This is based on the guidelines from the NCHE. All course units must conform to a standard set by the NCHE, such as minimum number of credit units, lecture hours, contact hours, tutorials and practicals among others. NCHE plays the oversight, regulatory and supervisory role in the development of academic programmes (Republic of Uganda, 2001). Materu (2007) points out that such review can produce significant results. Hence relative autonomy can be said to exist in process of academic programmes review. However, when the NCHE dictates on credit units, contact hours and the like, institutional autonomy and academic freedom get eroded because they infringe on the aspect of "the freedom to determine how to teach" inherent in the principle of institutional autonomy and academic freedom.

Programme accreditation is one of the mundane activities of NCHE as per the Universities and other Institutions Act (Republic of Uganda, 2001). Section 119 of the Act stipulates that "For avoidance of doubt, no person shall operate a university or other degree awarding institution without prior accreditation of its academic and professional programmes by the National Council for Higher Education". In practice, the NCHE accredits all academic programmes in HEIs in Uganda. According to Otto and Musinguzi (2013) the Council normally draws experts from the society, industry and academia both nationally and internationally to evaluate and vet programmes for accreditation. Programmes deemed to meet the requirements of the disciplinary field are then recommended for accreditation, while those which have fallen short are not. In so doing the NCHE gets involved in performing its legal role as per the Universities and Other Tertiary Institutions Act (Republic of Uganda, 2001). In making the ultimate decision whether a programme of study is worth teaching and therefore worth accrediting or not, the NCHE as a government would have usurped both institutional autonomy and academic freedom. Moreover, NCHE does not provide developers of academic programmes opportunity to argue their case as to whether a programme of study is relevant or not.

\section{Conclusion and Recommendations}

By far, institutional autonomy is still quite limited in determining the content and quality of university education in Uganda. Institutional autonomy is being curtailed at various levels particularly at the legislation level by parliament. There are quite a plethora of laws in place which hamper institutional autonomy. It is also being suppressed at operational level, for instance, the NCHE has many times denied universities opportunities to have their new or old programmes accredited (Otto \& Musinguzi, 2013). Indeed, absolute autonomy is clearly untenable as there are regulatory bodies, accountability bodies and direct interventions by government in matters of universities all over the world.

We recommend that universities should be given more room to determine the content of their education within the realms of the existing laws and regulations. Provided academic programmes are in line with national aspirations, development and review by the professiorate, and approval of such programmes by the University Senate should be deemed adequate. Therefore, academic programmes should be launched without approval of the National Council for Higher Education, the council may concentrate on other strategic issues.

Government should pass laws and regulations which are enabling for institutional autonomy and academic freedom to flourish. Laws curtailing academic programmes from being launched subject to accreditation by the National Council for Higher Education should be repealed. New laws allowing senior academic staff to develop academic programmes and have such programmes vetted by the Departmental Academic Boards, Faculty Boards and approved by the Senate for launching should be enacted.

The political elite such as the President and Ministers should avoid issuing instructions in respect to development, restructuring, teaching or scrapping of academic programmes. Such decisions should be left to academics to make based on evidence and not intuition. This is because, whereas some programmes of study may appear not be relevant to a non-expert, in the wisdom of the expert they may be crucially relevant for national development.

\section{References}

Ali, M., \& Shastri, R.K. (2010). Implementation of total quality management in higher Education. Asian Journal of Business Management, 2(1). 
Asiimwe, S., \& Steyn, G. M. (2013). Obstacles hindering the effective governance of universities in Uganda. Journal of Social Sciences, 34(1), 17-27.

Australian Vice-Chancellors Committee. (1989). The nature of a university and accompanying press release. Canberra.

Baldridge, J.V. (1971). Models of university governance: bureaucratic, collegial and political. Research and Development Memorandum. No. 77. Stanford Centre for Development and Teaching.

Bunoti, S. (2010). The quality of higher education in developing countries need professional support. Retrieved October 5, 2015, from www.intconfhighereducation.org.FINAL\%20Sarah\%20Bunoti.pdf

Business Dictionary. (2015). Definition of quality. Retrieved November 19, 2015, from $\mathrm{http}: / / \mathrm{www} \cdot$ businessdictionary.com/definition/quality.html\#ixzz14nV5cEH0

Chacha. (2004). reforming higher education in Kenya challenges, lessons and opportunities presented at the State University of New York workshop with the Parliamentary Committee on Education, Science and Technology Naivasha, Kenya. August 2004.

Chiang, L. (2004). The Relationship between university autonomy and funding in England and Taiwan. Higher Education, 48(2), 189-212. http://dx.doi.org/10.1023/B:HIGH.0000034314.77435.bf

Dee, J.R., Henkin, A.B., \& Chen, J.H. (2000). Faculty autonomy: perspectives from Taiwan. Higher Education, 44(2), 203-216. http://dx.doi.org/10.1023/A:1004009703603

Egeberg. (2004). Organising institutional autonomy in a political context: enduring tension in the European Commission's Development. ARENA Working Paper Series. University of Oslo.

Fisher, L.A. (1988). State legislature and the autonomy of colleges and universities. A comparative studies of legislation in four states, 1900-1979. Journal of higher education, 59(2). http://dx.doi.org/10.2307/1981690

Gellert, C. (1985). State intervention and Institutional Autonomy: university development and State Interference in England and West Germany. Oxford Review of Education, 11(3). http://dx.doi.org/10.1080/0305498850110308

Global Coalition to Protect Education from Attack. (2013). Institutional autonomy and the protection of higher education from attack. Retrieved March 11, 2016, from gcpea@protectingeducation.org

Gulu University. (2009). Gulu University strategic plan 2009/10-2018/19.

Gulu University. (2014). Annual report (2012-2013). Gulu University.

Kasozi, A.B.K. (2009). Financing Uganda's public universities: Fountain Publishers, Kampala.

Li, M., \& Yang, R. (2014). Governance reforms in higher education: A study of institutional autonomy China. In N.V. Varghese and M. Martin (Eds.), Governance reforms in higher education: A study of institutional autonomy in Asian countries. Paris: IIEP.

Makerere University. (2012). Annual report 2012.

Makerere University. (2013). Annual report 2013.

Makerere University. (2014). Annual report 2014.

Materu P. (2007). Higher education quality assurance in Sub-Saharan Africa status, challenges, opportunities, and promising practices. World Bank Working Paper, 124. http://dx.doi.org/10.1596/978-0-8213-7272-2

Mbarara University of Science and Technology. (2015). Mbarara University of Science and Technology Mission and Vision Retrieved November 20, 2015, from http://www.must.ac.ug/about-must/mission-vision

Muni University. (2011). Five year strategic plan 2010/11-2014/5.

National Council for Higher Education. (2001). Checklist for quality and university capacity indicators for assessment of universities and programmes under the Universities and Tertiary Institutions Act 2001.

National Council for Higher Education. (2008). Quality assurance framework for universities and the licensing procedure for higher education institutions. National Council for Higher Education.

National Council for Higher Education. (2010). The state of higher education in Uganda 2010: A report on higher education delivery and institutions. Kampala. National Council for Higher Education

National Council for Higher Education. (2011). Quality assurance framework for universities and the licensing process for higher education institutions. National Council for Higher Education 
National Council for Higher Education. (2013). The state of higher education in Uganda 2011: A report on higher education delivery and institutions. Kampala. National Council for Higher Education/

Nizam and Nurdin. (2014). Governance reforms in higher education: A study of institutional autonomy in Inodonesia. In Varghese, N.V. and Martin, M. (Eds.), Governance reforms in higher education: A study of institutional autonomy in Asian countries (2014). Paris: IIEP.

Ojo, J. D. (1990). Law and university administration in Nigeria. Malthouse Press Ltd

Okai, O. N., \& Worlu, P. (2014). University autonomy and academic freedom: Implication for Nigerian Universities. International Journal of Scientific research in Education, 7(2), 191-201.

Otto, F., \& Musinguzi, B. (2013). The accreditation process and challenges of private religious based universities in Uganda. International Journal of Pedagogical Innovations, 1(2), 89-95. http://dx.doi.org/10.12785/ijpi/010205

Republic of Uganda. (2005). Statutory instrument 2005, No. 85: the universities and other tertiary institutions (institutional standards) Regulations, 2005.

Taiwo, E.A. (2011). Regulatory Bodies, Academic Freedom and Institutional Autonomy in Africa: Issues and Challenges - The Nigerian Example. JHEA/RESA, 9(1 \& 2), 63-89.

Teferra, D. (2014). Charting African Higher Education. International Journal of African Higher Education, 1(1). http://dx.doi.org/10.6017/ijahe.v1i1.5642

Universities UK. (2015). Quality, equity, sustainability: the future of higher education.

Visalsok, T., Ngoy, M., \& Virak, Y. (2014) Governance reforms in higher education: A study of institutional autonomy Cambodia. In Varghese, N.V. and Martin, M. (Eds.), Governance reforms in higher education: A study of institutional autonomy in Asian countries (2014). Paris: IIEP. 